\title{
Cultural Change of Applying User Involvement for Improving Healthcare Quality: A Review of the Impact on Attitudes, Values and Assumptions among Healthcare Professionals and Users
}

\author{
DOI: 10.12776/QIP.V21I3.922
}

Jonas Boström, Helene Hillborg, Johan Lilja

\begin{abstract}
Purpose: The purpose of this study is to provide a review of the impact on culture (attitudes, values and assumptions) among both healthcare professionals, as well as users, when involving users for improving quality in healthcare.
\end{abstract}

Methodology/Approach: The paper is based on an extensive, narrative literature review considering studies that included professional's and users experiences of user involvement in quality improvement. The included articles were analyzed using an interpretive, along with a deductive, approach according to a theoretical framework.

Findings: The results indicate that there is currently limited research focusing on the impact of user involvement in quality improvement processes regarding professionals' and users' attitudes, values and/or assumptions. The articles identified during the study provides situations and statements, during the process of development, which can be interpreted as change in the culture. Although few articles specifically draw conclusions on user involvement as a "tool" for cultural change, the authors interpret several findings which strengthens that theory.

Research Limitation/implication: Research published in other databases could have been missed. The authors have tried to avoid this by using a snowball method reading references in identified articles.

Originality/Value of paper: The review provides a platform for both future research and the development of current practice within the area. There have been literature reviews showing obstacles and enablers when using patients, users and relatives in quality improvement work, but few which investigates cultural change. 
Category: Literature Review

Keywords: patient involvement; quality improvement; professionals; culture; service design

\section{INTRODUCTION}

Swedish healthcare, along with the western world healthcare systems in general, is currently facing major challenges and will probably not be able to produce enough healthcare in proportion to demand (Nordgren, 2009). People live for example longer, which increases the incidence of chronic diseases and drives the need for improving and developing accessibility and quality. A majority of the current healthcare resources, in terms of financial resources as well as personnel, are furthermore earmarked for patients with cancer, diabetes or cardiovascular diseases (The Swedish Agency for Health and Care Services Analysis, 2014). The Swedish Association of Local Authorities and Regions (SALAR) (2010), stresses in a letter of intent that the higher level of education among patients, technology development, and the simple access to information also tend to increase demand and expectations on healthcare services. Another trend that must be faced is that many people prefer and have come to expect a tailored solution in contact with service organizations (Quist and Fransson, 2014). Healthcare organizations are not generally structured to handle this demand for customization (Glouberman and Mintzberg, 2001a; SALAR, 2010).

Quality Improvement (QI) initiatives in healthcare often claim to have the customer or patient in focus (Bergman and Klefsjö, 2007). But despite the awareness that patients have the knowledge and overview of their own process, they are seldom a central part of the actual development process and the profession lets them assume a consultative rather than a decision-making role (Elg, et al., 2012; Gagliardi, et al., 2008).What is more, they are often not seen as a significant actor for the development of the health care services quality improvement activities (Groene, et al., 2009). On the other hand, Service Dominant Logic (SDL) stresses that if you really want, not only to have customers in focus, but to really get the patients focus to understand how improvements of the process leads to value, you can use service design thinking and methods (Quist and Fransson, 2014; Roberts, et al., 2015).

Methods and tools from service design have also shown a potential to make patients more active contributors of knowledge and skills for the quality improvement of healthcare services (Elg, et al., 2012). Currently, many projects are also initiated using this kind of approach within healthcare see e.g. (Elg, et al., 2012; Gustavsson, Gremyr and Sarenmalm, 2016; Lavoie-Tremblay, et al., 2014; Locock, et al., 2014; Piper, et al., 2012). However, this research has focused mostly on the forms, and how to use service design methods or tools, not on the impact on healthcare culture. One exception is Crawford, et al., (2002) systematic review on research of involving patients in the planning and 
development of healthcare, between 1965-2000, highlighting some effects on attitudes and mostly in mental health service. However, many sources of recent research (Brooks, 2008; Luxford, Safran and Delbanco, 2011) do highlight the need for change in healthcare culture in order to create favourable conditions for patient participation. Hence there is a need to specifically review the impact of various forms of user involvement on organizational and professional culture and attitudes. This is of special interest as the culture and attitudes towards user involvement undoubtedly have the potential to support as well as hinder future applications of service design thinking and tools for improving quality in healthcare as argued by e.g. (Armstrong, et al., 2013; Brooks, 2008; LavoieTremblay, et al., 2014).

\section{ORGANIZATIONAL AND PROFESSIONAL CULTURE}

To describe culture, this paper acknowledges Schein's (2010, p.18) definition stating that:

"The culture of a group can now be defined as a pattern of shared basic assumptions learned by a group as it solved its problems of external adaption and internal integration, which has worked well enough to be considered valid and, therefore, to be taught to new members as the correct way to perceive, think, and feel in relation to those problems."

In doing so, the essence of culture is seen as consisting of basic assumptions which are deeply embedded and unconscious in contrast to those artifacts you can observe with your senses, when you encounter a new group with an unfamiliar culture.

The manifestations of culture at different levels can also be understood with the "onion model" (Hofstede, Hofstede and Minkov, 2010, p.8). The different layers consisting of values, rituals, heroes and on the most superficial level are the symbols. The three outermost layers could be visible to an outside observer through practices, but their cultural meaning is invisible and only understood in the way these practices are interpreted by the insiders.

Professionals, like organizations, can develop strong cultures. According to Schein (2010) this is especially seen with highly educated professionals with strong connection to their work. These groups are defined with specific standards, values, fundamental beliefs and regulations. This will, consciously or subconsciously reflect on their approach, attitudes and behavior. These professional subgroups create a system containing a lot of specialized and strong cultures which inhibits a cooperative culture. Creating a common culture can be managed if people share beliefs and values. Then the different groups can coordinate their efforts (Glouberman and Mintzberg, 2001b).

Changing culture generally tend to demand will and motivation, which several management theories describe (French and Bell, 1999). Change, planned or 
unplanned, is then referred to as something that can be described as a new state of things compared to an old one. Changing culture can be understood by Schein's (2010) three-stage model of the change process that is built on Kurt Lewin's three stage model and ads psychological mechanisms to each step. Unfreezing in order to create motivation and readiness to change. Changing through Cognitive Restructuring by helping the client to experience, judge, and react to things differently based on a new point of view. And finally Refreezing through helping the client to integrate the new point of view. Burke (1994) also juxtaposes culture with change, stating that transformative change should focus on changing the employee's behaviors thru developing the organization's aims and strategies, it's leadership and the culture, in order to achieve deep and sustainable change. This will mean that members of the organization must unlearn something as well as learning something new (Schein, 2010).

In order to understand the complex healthcare system concerning obstacles for cooperation Glouberman and Mintzberg (2001a) identifies four "worlds" of healthcare and the characteristics within them as seen in Fig. 1. The figure distinguishes where and in what direction management is practiced. The horizontal cleavage in the system divides those who operate clinically "down" from those who work "up". The vertical cleavage divides the nurses and managers who are close to the institution, from the physicians and trustees, which are involved but not so formally committed. Glouberman and Mintzberg (2001a) further emphasize that unless the organizations (healthcare) find ways to establish connections between these worlds, nothing fundamental will change.

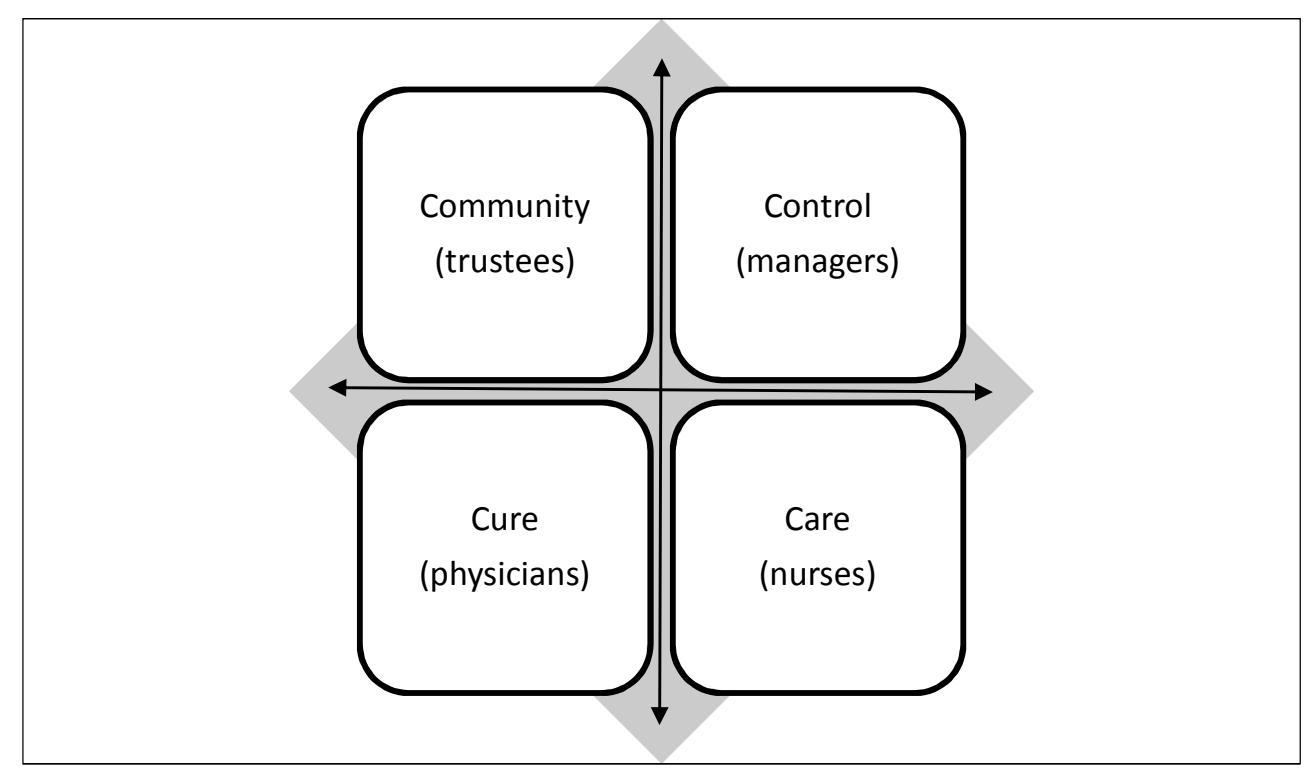

Figure 1 - Four Worlds of the General Hospital inspired by Glouberman and Mintzberg (2001a, p.57) 
The purpose of this study is to provide a review of the impact on culture (attitudes, values and assumptions) among both healthcare professionals, as well as users, when involving patients for the improvement of quality in healthcare.

\section{METHODOLOGY}

The literature study of this paper was inspired by the extended narrative review as presented by Bryman (2011). The review considered studies that included professional's experiences of user involvement in quality improvement along with studies that described the impact on healthcare culture. The included articles were analyzed using an interpretive along with a deductive approach according to theories from organizational and professional culture.

\subsection{Search Strategy}

The search strategy aimed to find studies performed in a healthcare context. By using Mesh-terms and Thesaurus such as "patient participation", "consumer participation", "client participation", "organizational culture", "attitude of health personnel", and "quality improvement" as well as keywords such as "impact", "service design", and "change management" in the databases Pubmed, Cinahl and Psychinfo, a total quantity of 3,786 articles were found.

\subsection{Selection Criteria}

Inclusion criteria were a focus on user/patient involvement, and that the articles had described user involvement at least on the level of partnership according to the Arnstein ladder of participation (Arnstein, 1969). Further inclusion criteria were a connection to quality improvement activities, full text access, english language, peer-reviewed and published between 2000-2016. Clinical trials, shared decision making (SDM), education and descriptions of other personnel outside a healthcare context were excluded.

\subsection{Analysis}

The first author started the analysis by reading all of the article titles. A second selection was then made by reading the abstracts of all the remaining articles, which led to 83 articles where full text was read as seen in Fig. 2. During this review, 12 additional articles were found using snowball methodology. The first and second author then also read the remaining 24 selected articles to discover which described impact on cultural change. All of these articles were rated, discussed and compared in relation to the purpose of the review. As a result, six articles were finally selected for a detailed thematic analysis in accordance to Patton (2014).

The first and second author then contracted sentences, sets of sentences and citations which were coded and then interpreted into three categories (attitudes, 
values, and assumptions) and in a chronological order (before, during, and after the different user involvement activities).

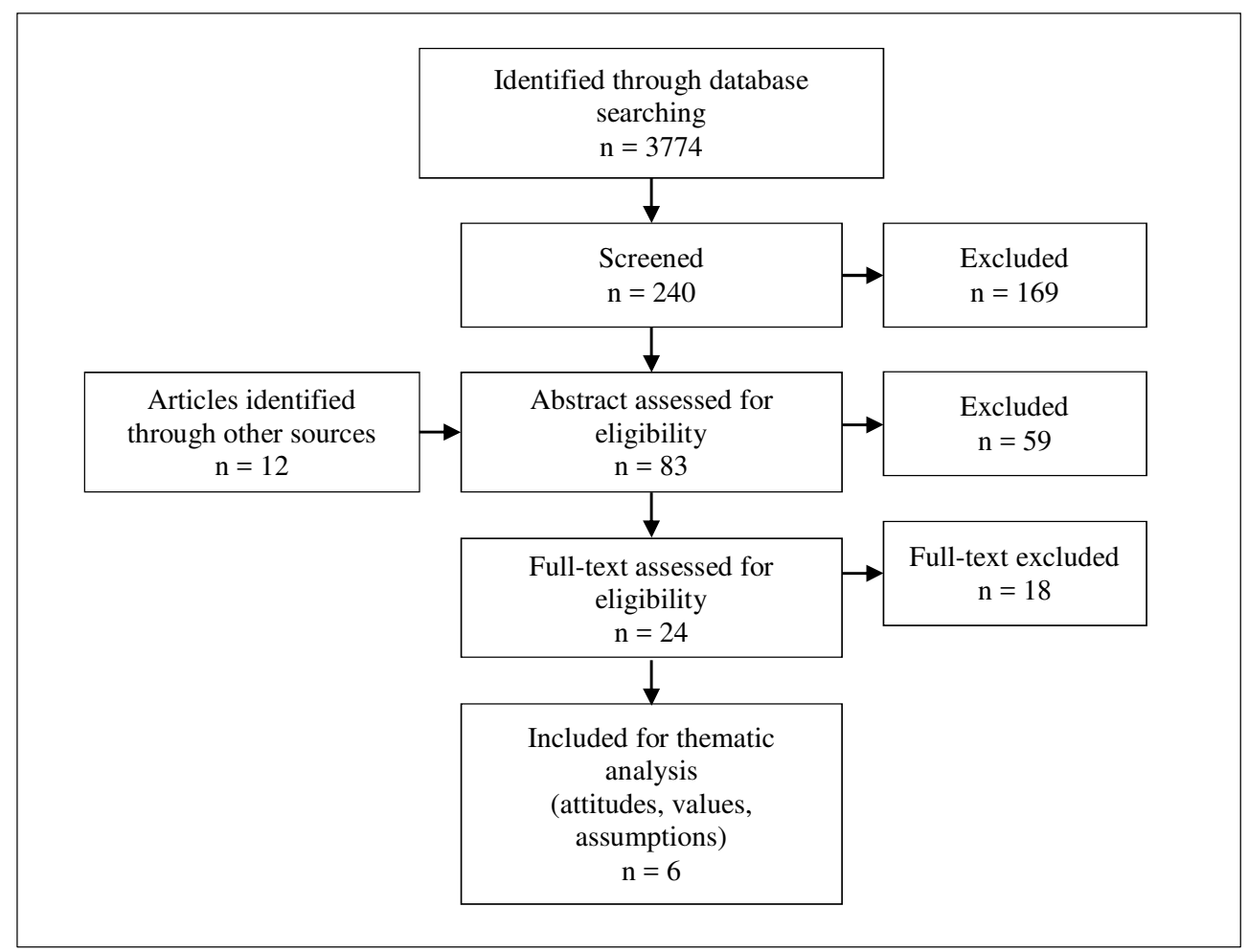

Figure 2 - The Methodology of the Literature Study, Systematically Narrowing Down the Selection of Identified Articles Stepwise

\section{RESULTS}

As a result of the review process, the content of the selected articles was summarized in a chronological order in relation to user involvement activities, as presented in the sections below. The collective picture is emerging from the analysis of the articles concerning the journey before, during, and after involving users in health care quality development, could very well be referred to as "a journey from resistance to appreciated insights".

\subsection{Before User Involvement: We Know!}

Initially, the articles suggest that there are signs that the professionals see themselves as carriers of knowledge. They also tend to assume that their knowledge is superior to that of the users'. This is exemplified in users describing their presence in various development teams, only to say yes, or agree, to conclusions already drawn up and presented by the healthcare personnel. "It sounds as though we are here to say ok to the trust decisions (hospital), agree 
with them" (Brooks, 2008, p.8). And the professionals tend to express that the "patients councils" wouldn't necessarily know enough about the needs in the healthcare organization. In sum, users comment that they feel that their knowledge is not highly valued in the development processes.

One reason described in the articles concerning why members of the health care organizations should involve users is that they are bound to do so to follow legislations and /or policies, they have to "tic the box". There are doubts as to the user's knowledge and their ability to contribute with their experience. There are also descriptions of professional attitudes when they want to select the "right" patients to participate in the development team and that "their" patients are too vulnerable or that they "soon will die". Professionals thoughts about their own knowledge and competence skills regarding improvement work, justifies the right to decide who is best to participate in involvement activities, which is, on the one hand, strengthened by the expressed feeling from users, of not being trusted with the capability to represent a larger group than themselves. And, on the other hand, the fears expressed among the professionals about exposing their weaknesses: "Because at first, when I heard patient rep, I'm thinking oh my god! We're gonna expose ourselves, to strangers ... because our practice was so that we work with our team. We work with ourselves. We're comfortable as a health care team. We speak the same language or so we think. That's the perception. So to bring a patient in, you're thinking oh my god! I'm exposing all of myself so they'll see all of my imperfections ... that was at the back of my mind at first, but then once they're there, you're thinking wow! It's great having them because they have input and they have valuable information that you can use" (LavoieTremblay, et al., 2014, p.43).

In contrast to the descriptions above, there are examples where health care professionals reveal confidence about the user's ability to contribute with new ideas, experiences and competence, that are valuable for the improvement work. "I think it's a good thing...after all, patients have good ideas..." (LavoieTremblay, et al., 2014, p.43). Several users also express their possibilities to act as a resource because of their access to knowledge and experiences that the professionals lack and they feel an obligation to "pay back" (Cotterell, et al., 2011, p.163).

\subsection{During User Involvement: Maybe We Can?}

The articles also describe, that during development work in which users were involved, there was an ambiguity as to what is expected in the cooperation. Both users and professionals showed signs of "not knowing" how to behave, act in relation to each other, and the roles seemed unclear. The professionals also depict the users as threatening, annoying and ungrateful and the users felt that there seemed to be insignificant experience of handling criticism within the professional's organization. 
One project displayed better experiences in the cooperation but they had also selected user representatives that they already knew had a positive attitude towards their organization. Other professionals expressed that interaction with users who had personal expertise and knowledge of healthcare (former healthcare workers) would be preferred as a team member.

The articles also provide clear descriptions of professionals using various power techniques, such as silence about uncomfortable topics, trying to lead discussions back to their agenda, and the use of bureaucratic language. Users feel that some discussions are superficial and signs of tokenism are significant (tick the box). There was also a clear sense of the hierarchic structure "it puts a barrier up, an unconscious barrier.... Their name, rank and serial number” (Forbat, et al., 2009, p.88).

Over time the cooperation tends to develop into more of an understanding of each other's contribution. Users felt for example that the professionals started to value their experiences and stories as important knowledge for the improvement work. There were examples were professionals preconceptions about difficulties with user involvement proved groundless and they increased their understanding that user participation matters.

The different projects also gave examples of greater insights on how power relations and hierarchical structure affected users ability to participate on equal terms, "There was a real move forward. I felt that there was trust" (Martin and Finn, 2011, p.1059). Furthermore, participation in the improvement work also created a sense of empowerment and as a supporting activity to the user's recovery process (cancer patients). "It isn't a support group but my God it's a support group (laughter)” (Cotterell, et al., 2011, p.165).

\subsection{After User Involvement: They're OK!}

At the end of user involvement projects, a majority of the analyzed material, stresses a lot of descriptions of how the professional's view of user involvement had changed. Long term skepticism had often developed into a trustful relationship. The professional's attitudes to the patient perspective also affected the ability to resolve potential conflict situations during cooperation in a positive way. Both groups expressed a better understanding of the complexity of cross functional teamwork. Users experiences tend to contribute to a shift in power relations as the professional now saw the value of the user's stories and gained an insight that they couldn't argue against. "I think we naively sort of missed a trick there because I, we, took it the wrong way, we said that some of our patients had an obsession about linen or something, and we didn't know why until we did the storytelling. It isn't an obsession, it is a desire to put things right. Those stories had a real impact on me, I have been in nursing $17 \mathrm{yr}$. and never heard them before" (Brooks, 2008, p.10). 
More details about the specific involvement methods used, the participants involved, and the specific findings regarding cultural change from each article is seen in Tab. 1.

Table 1 - A Specification of the Involvement Methods Used, the Participants Involved and the Specific Findings Regarding Cultural Change from each of the Six Articles Selected for the Detailed Thematic Analysis

\begin{tabular}{|c|c|c|c|c|c|}
\hline $\begin{array}{l}\text { Author, } \\
\text { Year }\end{array}$ & Title & Country & $\begin{array}{c}\text { Involvement } \\
\text { method }\end{array}$ & $\begin{array}{l}\text { Partici- } \\
\text { pants }\end{array}$ & $\begin{array}{c}\text { Findings regarding } \\
\text { Cultural Change }\end{array}$ \\
\hline $\begin{array}{l}\text { Armstron, } \\
\text { et al., } \\
2013\end{array}$ & $\begin{array}{l}\text { Optimizing } \\
\text { patient } \\
\text { involvement in } \\
\text { quality } \\
\text { improvement }\end{array}$ & UK & $\begin{array}{l}\text { Service user } \\
\text { participation } \\
\text { in strategic } \\
\text { level health } \\
\text { care } \\
\text { decision- } \\
\text { making }\end{array}$ & $\begin{array}{l}\text { Users, } \\
\text { Physician, } \\
\text { Nurses }\end{array}$ & $\begin{array}{l}\text { Citations from } \\
\text { personnel and users } \\
\text { about feelings and } \\
\text { experiences } \\
\text { Rationales to } \\
\text { involvement } \\
\text { Observations of } \\
\text { behaviors }\end{array}$ \\
\hline $\begin{array}{l}\text { Brooks, } \\
2008\end{array}$ & $\begin{array}{l}\text { Nursing and } \\
\text { public } \\
\text { participation in } \\
\text { health: An } \\
\text { ethnographic } \\
\text { study of a patient } \\
\text { council }\end{array}$ & UK & $\begin{array}{l}\text { Service user } \\
\text { participation } \\
\text { in strategic } \\
\text { level health } \\
\text { care } \\
\text { decision- } \\
\text { making }\end{array}$ & $\begin{array}{l}\text { Users, } \\
\text { Nurses }\end{array}$ & $\begin{array}{l}\text { Citations from } \\
\text { personnel and users } \\
\text { about feelings and } \\
\text { experiences } \\
\text { Nurse-Patient } \\
\text { partnership } \\
\text { Communication } \\
\text { strategies }\end{array}$ \\
\hline $\begin{array}{l}\text { Cotterell, } \\
\text { et al., } \\
2011\end{array}$ & $\begin{array}{l}\text { Service user } \\
\text { involvement in } \\
\text { cancer care: the } \\
\text { impact on service } \\
\text { users }\end{array}$ & UK & $\begin{array}{l}\text { Service users } \\
\text { affected by } \\
\text { cancer were } \\
\text { engaged in } \\
\text { involvement } \\
\text { activities in } \\
\text { cancer } \\
\text { service, care } \\
\text { and research }\end{array}$ & Users & $\begin{array}{l}\text { Citations from users } \\
\text { about feelings and } \\
\text { experiences } \\
\text { Value aspects }\end{array}$ \\
\hline $\begin{array}{l}\text { Forbat, et } \\
\text { al., } 2009\end{array}$ & $\begin{array}{l}\text { Engaging patients } \\
\text { in health care: An } \\
\text { empirical study of } \\
\text { the role of } \\
\text { engagement on } \\
\text { attitudes and } \\
\text { action }\end{array}$ & UK & $\begin{array}{l}\text { Lung Cancer } \\
\text { teams engage } \\
\text { with patients } \\
\text { and family } \\
\text { members } \\
\text { (supported } \\
\text { collaboration } \\
\text { ) for 6 } \\
\text { months }\end{array}$ & $\begin{array}{l}\text { Users, } \\
\text { Physician, } \\
\text { Nurses }\end{array}$ & $\begin{array}{l}\text { Citations from } \\
\text { personnel and users } \\
\text { about feelings and } \\
\text { experiences } \\
\text { Attitude change } \\
\text { Tokenism }\end{array}$ \\
\hline $\begin{array}{l}\text { Lavoie- } \\
\text { Tremblay, } \\
\text { et al., } \\
2014\end{array}$ & $\begin{array}{l}\text { The perceptions } \\
\text { of Health Care } \\
\text { Team Members } \\
\text { About Engaging } \\
\text { Patients in Care } \\
\text { Redesign }\end{array}$ & Can & $\begin{array}{l}\text { Patient } \\
\text { representativ } \\
\text { es in care } \\
\text { redesign } \\
\text { teams from } \\
\text { start }\end{array}$ & $\begin{array}{l}\text { Users, } \\
\text { Physician, } \\
\text { Nurses }\end{array}$ & $\begin{array}{l}\text { Citations from } \\
\text { personnel and users } \\
\text { about feelings and } \\
\text { experiences } \\
\text { Transformation process }\end{array}$ \\
\hline
\end{tabular}




\begin{tabular}{|l|l|l|l|l|l|}
\hline \multicolumn{1}{|c|}{$\begin{array}{c}\text { Author, } \\
\text { Year }\end{array}$} & \multicolumn{1}{|c|}{ Title } & Country & $\begin{array}{l}\text { Involvement } \\
\text { method }\end{array}$ & $\begin{array}{l}\text { Partici- } \\
\text { pants }\end{array}$ & \multicolumn{1}{|c|}{$\begin{array}{c}\text { Findings regarding } \\
\text { Cultural Change }\end{array}$} \\
\hline $\begin{array}{l}\text { Martin } \\
\text { and Finn, } \\
2011\end{array}$ & $\begin{array}{l}\text { Patients as team } \\
\text { members: } \\
\text { opportunities, } \\
\text { challenges and } \\
\text { paradoxes of } \\
\text { including patients } \\
\text { in multi- } \\
\text { professional } \\
\text { healthcare teams }\end{array}$ & UK & $\begin{array}{l}\text { Patient } \\
\text { representativ } \\
\text { es in } \\
\text { management } \\
\text { teams }\end{array}$ & $\begin{array}{l}\text { Users, } \\
\text { Physician, } \\
\text { Nurses }\end{array}$ & $\begin{array}{l}\text { Citations from } \\
\text { personnel and users } \\
\text { about feelings and } \\
\text { experiences } \\
\text { Tensions }\end{array}$ \\
\hline
\end{tabular}

\section{CONCLUSION}

Given the purpose of this paper, to provide a review of the impact on culture (attitudes, values and assumptions) among healthcare professionals, as well as users, when involving users for improving quality in healthcare, the results of this literature review contribute with several conclusions.

A first conclusion is that the conducted review reveals a currently limited level of research in this area. Starting out from the initial hits with 3786 articles, in the end only six articles were found that actually covered this topic in a way that could be seen as a cultural change within the professional groups. Even fewer articles could be found that focuses on users/patients experiences associated to attitudes, values and assumptions in cooperation during quality improvement processes in a healthcare context.

Secondly, the results indicate that culture in terms of for example basic assumptions are indeed impacted by user involvement for quality improvement in health care. In applying a chronological perspective, the analysis and results indicate e.g. extensive changes in attitudes among both healthcare professionals and users such as patients. The change of attitudes highlighted in several cases can be summarized as a journey from resistance to appreciated insights. Initially common attitudes of e.g. fear and a lack of trust are often impacted positively and are reduced and even replaced by attitudes such as respect and even appreciation.

The identified articles also underline various impacts of user involvement on other cultural aspects such as behaviors. The change of behaviors resulting from user involvement is presented as a reduction in for example the use of power strategies when healthcare professionals and patients are interacting. 


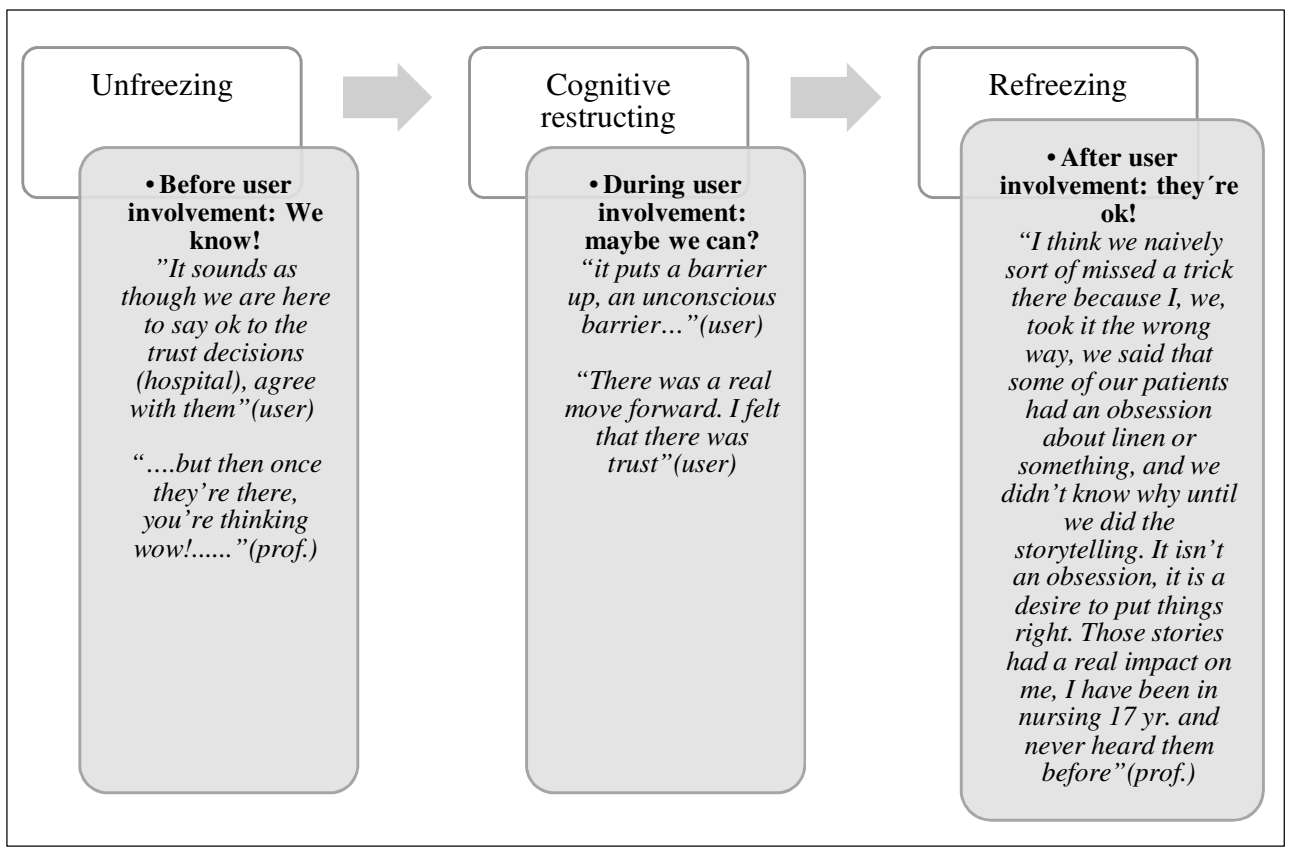

Figure 3 - The Process of Change among Healthcare Professionals and Users in Relation to Scheins Model of Change (Schein, 2010)

\section{DISCUSSION AND FUTURE RESEARCH}

Putting the results in perspective, the conclusions of this study contributes with a unique review concerning the impact on culture (attitudes, values and assumptions) among the professionals, as well as users, when involving users for improvement of quality in healthcare. Co-creation through a design thinking perspective could manifest the diverse lawyers of culture, from the values/basic assumptions to the symbols/artifacts as described by Hofstede, Hofstede and Minkov (2010) and Schein (2010).

The conclusions furthermore stress that the impact described, in the few identified articles covering the topic, is actually often large and positive. Involving users for improving quality in healthcare appears to be a strong potential driver of cultural change (having an impact on attitudes, values and assumptions) among both healthcare professionals and users. This might be a key to addressing the challenge highlighted in previous research, stating that despite the awareness that patients have the knowledge and overview of their own process, they are seldom a central part of the actual development process and the profession lets them assume a consultative rather than a decision-making role (Elg, et al., 2012; Gagliardi, et al., 2008). Involving users in improvement work could also be one way to create connections between the worlds of "Cure", "Care", and "Community" as defined by Glouberman and Mintzberg (2001a), and by this influence collaboration activities as a feasibility for fundamental cultural change. 
Even more generally, the conclusions contribute to an ongoing discourse within quality management concerning as to whether culture or tools/methodologies come first, or even should come first as for example discussed by Tari and Sabater (2004), and Hellsten and Klefsjö (2000). The conclusions of this study suggest that in many cases the desirable culture appear to actually follow as a result of starting to apply tools and methodologies of user involvement in health care quality development.

When it comes to future research, the results found in this review do, as said, clearly suggest the need for future research that focuses on the cultural journey. It would furthermore be interesting to see more research being conducted in a context outside the UK, as most of the previous research identified here appears to have been conducted in the UK. More specifically, future research should preferably consider the culture among health care professionals and users before various forms of involvement and then compare them with the culture emerging after user involvement, from a short and long term perspective. Among the more specific research questions the following would be of great interest for further studies:

- How does user involvement affect future quality improvement programs?

- How sustainable are the cultural impacts of user involvement in healthcare quality development?

- What forms of user involvement have the largest and most sustainable impact on the culture (attitudes, values and assumptions) among the professionals, as well as users?

\subsection{Limitations}

The review held some limitations as articles published prior to the year of 2000 were excluded and a wider search in other databases outside a healthcare context could have revealed more articles/quality improvement examples to analyze.

\section{REFERENCES}

Armstrong, N., Herbert, G., Aveling, E.L., Dixon-Woods, M. and Martin, G., 2013. Optimizing patient involvement in quality improvement. Health Expectations, 16(3), pp.36-47.

Arnstein, S.R., 1969. A ladder of citizen participation. Journal of the American Institute of Planners, 35(4), pp.216-224.

Bergman, B. and Klefsjö, B., 2007. Kvalitet från behov till användning (Quality from need to use). Lund: Studentlitteratur AB.

Brooks, F., 2008. Nursing and public participation in health: an ethnographic study of a patient council. International Journal of Nursing Studies, 45(1), pp. 313. 
Bryman, A., 2011. Social Research Methods. 3rd ed. Malmö: Liber AB.

Burke, W., 1994. Organisational Development: A process of learning and changing. Boston: Addison-Wesley Publishing Company.

Cotterell, P., Harlow, G., Morris, C., Beresford, P., Hanley, B., Sargeant, A., Sitzia, J. and Staley, K., 2011. Service user involvement in cancer care: the impact on service users. Health Expectations, 14(2), pp.159-69.

Crawford, M.J., Rutter, D., Manley, C., Weaver, T., Bhui, K., Fulop, N. and Tyrer, P., 2002. Systematic review of involving patients in the planning and development of health care. British Medical Journal, 325(7375), pp. 1263.

Elg, M., Engström, J., Witell, L. and Poksinska, B.B., 2012. Co-creation and learning in health-care service development. Journal of Service Management, 23(3), pp.328-343.

Forbat, L., Cayless, S., Knighting, K., Cornwell, J. and Kearney, N., 2009. Engaging patients in health care: An empirical study of the role of engagement on attitudes and action. Patient Education and Counseling, 74(1), pp.84-90.

French, W.L. and Bell, C.H., 1999. Organization development: behavioral science interventions for organization improvement. New Jersey: Prentice-Hall, Upper Saddle River.

Gagliardi, A.R., Lemieux-Charles, L., Brown, A.D., Sullivan, T. and Goel, V., 2008. Barriers to patient involvement in health service planning and evaluation: an exploratory study. Patient Education and Counseling, 70(2), pp.234-241.

Glouberman, S. and Mintzberg, H., 2001a. Managing the care of health and cure of disease - Part I: Differentiation. Health Care Management Review, 26(1), pp.56-59.

Glouberman, S. and Mintzberg, H., 2001b. Managing the care of health and cure of disease - Part II: Integration. Health Care Management Review, 26(1), pp.7084.

Groene, O., Lombarts, M.J.M.H., Klazinga, N., Alonso, J., Thompson, A. and Suñol, R., 2009. Is patient-centeredness in European hospitals related to existing quality improvement strategies? Analysis of a cross-sectional survey (MARQuIS study). Quality and Safety in Health Care, 18(1), pp.44-50.

Gustavsson, S., Gremyr, I. and Sarenmalm, E.K, 2016. Designing quality of care - contributions from parents: Parents' experiences of care processes in pediatric care and their contribution to improvements of the care process in collaboration with healthcare professionals. Journal of Clinical Nursing, 25(5-6), pp.742-751.

Hellsten, U. and Klefsjö, B., 2000. TQM as a management system consisting of values, techniques and tools. TQM Magazine, 12(4), pp.238-244. 
Hofstede, G., Hofstede, G.J. and Minkov, M., 2010. Cultures and Organizations: software of the mind: intercultural cooperation and its importance for survival. 3rd ed. London: McGraw-Hill.

Lavoie-Tremblay, M., O'Connor, P., Harripaul, A., Biron, A., Ritchie, J., Mac Gibbon, B. and Cyr, G. 2014. The Perceptions of Health Care Team Members About Engaging Patients in Care Redesign. American Journal of Nursing, 114(7), pp. 38-48.

Locock, L., Robert, G., Boaz, A., Vougioukalou, S., Shuldham, C., Fielden, J., Ziebland, S., Gager, M., Tollyfield, R. and Pearcey, J., 2014. Using a national archive of patient experience narratives to promote local patient-centered quality improvement: an ethnographic process evaluation of 'accelerated' experiencebased co-design. Journal of Health Services Research \& Policy, 19(4), pp. 200207.

Luxford, K., Safran, D.G. and Delbanco, T., 2011. Promoting patient-centered care: a qualitative study of facilitators and barriers in healthcare organizations with a reputation for improving the patient experience. International Journal for Quality in Health Care, 23(5), pp.510-515.

Martin, G.P. and Finn, R., 2011. Patients as team members: opportunities, challenges and paradoxes of including patients in multi-professional healthcare teams. Sociology of Health \& Illness, 33(7), pp.1050-1065.

Nordgren, L. 2009. Value creation in health care services - developing service productivity: Experiences from Sweden. International Journal of Public Sector Management, 22(2), pp.114-127.

Patton, M.Q., 2014. Qualitative research \& evaluation methods. 4th ed. Thousand Oaks, CA: Sage Publications Inc.

Piper, D., Iedema, R., Gray, J., Verma, R., Holmes, L. and Manning, N., 2012. Utilizing experience-based co-design to improve the experience of patients accessing emergency departments in New South Wales public hospitals: an evaluation study. Health Services Management Research, 25(4), pp.162-172.

Quist, J. and Fransson, M., 2014. Tjänstelogik för Offentlig förvaltning - en Bok för Förnyelsebyråkrater (Servicelogic for Public administration - a Book for Renewalbureaucrats). Stockholm: Liber AB.

Roberts, J.P., Fisher, T.R., Trowbridge, M.J. and Bent, C., 2015. A design thinking framework for healthcare management and innovation. Healthcare, 4(1), pp.11-14.

Schein, E.H., 2010. Organizational Culture and Leadership. San Francisco: Jossey-Bass, CA. 
Tari, J.J. and Sabater, V., 2004. Quality tools and techniques: are they necessary for quality management?. International journal of production economics, 92(3), pp.267-280.

The Swedish Agency for Health and Care Services Analysis, 2014. VIP $i$ vården? - Om utmaningar $i$ vården av personer med kronisk sjukdom (VIP in healthcare? - About challenges in care of individuals with chronic diseases). [pdf] Stockholm: Vårdanalys. Available at: <http://www.vardanalys.se/Global /Rapporter\%20pdf-filer/2014/2014-2-VIP\%20i\%20v\%C3\%A5rden.pdf $\geq$ [Accessed 22 March 2016].

The Swedish Association of Local Authorities and Regions (SALAR), 2010. Patient och brukarmedverkan- Positionspapper - för ökad kvalitet och effektivitet I hälso- och sjukvård och socialtjänst (Patient and user involvement Letter of Intent - for increased quality and effiency in healthcare and social services). [pdf] Stockholm: The Swedish Association of Local Authorities and Regions. Available at: <https://skl.se/download/18.59311cdd145ac7ef71c7 a945/1399972804500/SKL+Positionspapper+Patient+och+brukarmedverkan.pdf> [Accessed 23 March 2016].

\section{ABOUT AUTHORS}

Jonas Boström, PhD Student; Mid Sweden University; Research and Development, Västernorrland County Council, Sundsvall, Sweden. Practical experience from quality improvement projects as well as project management and coaching related to service design and development processes in healthcare. E-mail: jonas.bostrom@lvn.se.

Helene Hillborg, PhD., Research and Development, Västernorrland County Council, Sundsvall, Sweden. Practical and research experience focused on user involvement, empowerment interagency collaboration and implementation related to rehabilitation and recovery in healthcare and social services. E-mail: helene.hillborg@lvn.se.

Johan Lilja, Lecturer, PhD., Mid Sweden University, Östersund, Sweden. Practical and research experiences as well as supervision and project management related to quality management, design, innovation and process management, specifically related to customer value and attractive quality creation. E-mail: johan.lilja@miun.se.

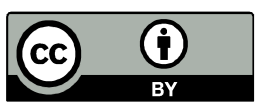

(C) 2017 by the authors. Submitted for possible open access publication under the terms and conditions of the Creative Commons Attribution (CC-BY) license (http://creativecommons.org/licenses/by/4.0/). 